Final version to appear in Critical Philosophy of Race.

\title{
Feeling Racial Pride in the Mode of Frederick Douglass ${ }^{1}$
}

\author{
Jeremy Fischer
}

\begin{abstract}
Drawing on Frederick Douglass's arguments about racial pride, I develop and defend an account of feeling racial pride that centers on resisting racialized oppression. Such pride is racially ecumenical in that it does not imply partiality towards one's own racial group. I argue that it can both accurately represent its intentional object and be intrinsically and extrinsically valuable to experience. It follows, I argue, that there is, under certain conditions, a morally unproblematic, and plausibly valuable, kind of racial pride available to White people, though one that could hardly differ more from what is generally meant by "White pride."
\end{abstract}

Keywords: emotion, Frederick Douglass, pride, race, racial oppression, Whiteness

\section{Introduction}

In an 1889 speech, entitled "The Nation's Problem," Frederick Douglass declared, "the whole assumption of race pride is ridiculous. Let us have done with complexional superiorities or inferiorities, complexional pride or shame."2 Douglass was probably not the first, and certainly not the last, prominent thinker to critique racial pride.

Despite this history of critique, many still endorse racial pride. For example, a 2009 Associated Press article, entitled "Mays: So proud when Obama elected that he cried," reported that Willie Mays, the great athlete who helped to desegregate Major League Baseball, said that he long hoped for a Black American to be elected to the presidency. Of Barack Obama's election in 2008, Mays reflected, "that tells me all the things I went through, it was for good things. . So I'm just proud of him [Obama], you know. He may be proud of something else. But I'm proud of him, what he stands for."3

Mays's remark expresses several related emotions: pride about his role in integrating America and paving the way for a Black president; pride in Barack Obama; and pride about what Barack Obama stands for (perhaps the decreasing racism of White America). This type of sentiment is powerful and commonplace. It is plausible to call it

1. For their helpful feedback on drafts of this paper, I am grateful to Ben Almassi, Monica Aufrecht, Lars Enden, Asia Ferrin, David H. Kim, Ann Levey, Brandon Morgan-Olsen, Jean Roberts, David Stoval, Andrea Sullivan-Clarke, Bill Talbott, and two anonymous referees for this journal. I am particularly grateful to Rachel Fredericks, who provided helpful comments on multiple drafts of this paper. I am also grateful to the organizers and audiences the 2012 International Social Philosophy Conference and the 2012 Northwest Philosophy Conference.

2. Frederick Douglass, "The Nation's Problem," in Philip Foner, ed., Frederick Douglass: Selected Speeches and Writings (Chicago: Chicago Review Press, 2000), 725-740; 731.

3. Darlene Superville, "Mays: So proud when Obama elected that he cried," Associated Press, July 14, 2009. 
"racial pride" or, more specifically, "Black pride." However, there are puzzles about what racial pride is and whether it is ever justified.

Racial pride is spoken of in many ways. It can be intelligibly invoked in relation to social movements for either racial justice or racial injustice, self-respect or supremacy over others, and solidarity or animosity. Racial pride inherits much of its multifariousness from the descriptive and normative ambiguities of pride itself, which Adrienne Rich aptly described as "a tricky, glorious, double-edged feeling." 4 Pride can express or involve arrogance, conceitedness, and vanity, as well as self-respect and a proper pleasure in one's achievements. ${ }^{5}$

Racial pride is an especially complex form of pride. Unlike, say, pride in one's beautiful house, it is sometimes unclear what racial pride is about or whether some instance of pride qualifies as racial pride. Indeed, some dispute whether race even exists and, if it does, what sort of thing it is. This descriptive indeterminacy complicates evaluation of the emotion by, for instance, obscuring moral asymmetries. ${ }^{6}$ For, if racial groups are partly individuated by their location within an unjust socio-political hierarchy, and if White and Black racial groups are defined partly in terms of unjust advantage and corresponding disadvantage (as I suspect they are), then pride in being White can reflect morally objectionable judgments in a way that pride in being Black cannot.

Thus, it may come as no surprise that I will argue that there are many kinds of racial pride. However, I will also argue that, in the end, some kinds are nearer to the core of this phenomenon than others. In particular, pride felt in resisting or overcoming racialized oppression is central, in a sense to be explained, to many or most forms of racial pride.

Moreover, there are many dimensions along which racial pride can be evaluated. For instance, as Douglass's speech illustrates (discussed further in $§ 4.1$ ), it is sometimes claimed that one should feel pride only about achievements, and never about such things as beautiful complexions or hair. However, this "should" is ambiguous: is it based in prudential considerations? Or moral considerations? Or epistemic considerations? In this essay, I pursue the neglected question of how different sorts of racial pride stand up to different standards of evaluation.

One conclusion that I draw is that, because our evaluation of pride is a function of many descriptive and normative variables, any unconditional endorsement or rejection of racial pride brings with it an argumentative burden that cannot be met. Some forms of it-especially, I argue, forms that center on resisting or overcoming racialized oppression - tend to be appropriate, all things considered. However, other forms of racial pride should be met with skepticism or ambivalence, at best.

4. Adrienne Rich, "If Not with Others, How?" in Blood, Bread, and Poetry (New York: W.W. Norton, 1986), 204. I discuss these ambiguities in my "Feeling Proud and Being Proud: Emotion, Character, and the Moral Psychology of Personal Ideals," The Journal of Value Inquiry 46 (2012): 209-222.

5. See Gabriele Taylor, Deadly Vices (New York: Oxford University, 2004); and my "The Ethics of Reflexivity: Pride, Self-Sufficiency, and Modesty," Philosophical Papers 45(3), (2016): 365-399.

6. See Lawrence Blum, “I'm Not a Racist, But ...”: The Moral Quandary of Race (Cornell University Press, 2002); and Samantha Vice, "White Pride," The Moral Psychology of Pride, J. Carter, E. Gordon, eds. (London: Rowman and Littlefield, 2017): 191-210. 
Surprisingly, given the remark quoted at the start of the paper, I find that these conclusions are consistent with Douglass's own thinking on the matter. Notwithstanding his explicit and unequivocal disparagement of what he calls "race pride," Douglass in fact supports what I will argue is a different kind of racial pride. And we should too.

In $\S 2$, I survey four important kinds of racial pride discussed in the literature. These kinds differ according to the emotion's intentional object or, in other words, what the emotion is about. In $\S 3$, drawing on Douglass, I introduce a fifth kind of racial pride that is about resistance to racialized oppression, and argue that such pride is central to many or most forms of racial pride. In $\S 4$, I critically survey a variety of evaluative claims commonly made about the emotion of racial pride. I argue that racial pride can accurately represent its intentional object and that feeling racial pride can have positive intrinsic and extrinsic value.

These arguments are not intended as presumptuous decrees about how racially oppressed people should value themselves. Rather, I offer them with an eye towards determining what forms of anti-racist racial pride might be available to White people, like myself, and thus towards answering the question posed by Lucius Outlaw (among others) of what "the particular positive, constructive race-formational aspects of whiteness, what the forms and instantiations of transformed, rehabilitated notions of whiteness must be." 7 So, in $\S 5$, I consider the case of White people who feel pride about their own or others' anti-racist achievements. I argue that, under certain limited conditions, such pride is a morally unobjectionable resource for developing anti-racist civic agency in White people. I conclude the essay, in $\$ 6$, by noting that further work is needed to make sense of the academically neglected character trait of racial pride and its relation to the emotion of racial pride discussed here.

\section{The Emotions of Racial Pride}

In a classic defense of racial pride, Bernard Boxill astutely distinguishes between three types of the occurrent emotion of Black pride on the basis of each type's characteristic intentional object. ${ }^{8}$ The first type is pride in one's racialized bodily appearance, such as pride in the color of one's skin, one's facial features, or the texture and color of one's

hair. Somatic racial pride often involves aesthetically valuing the racialized body (e.g., "Black is Beautiful"). Such pride is sometimes described as pride in one's racial

7. Lucius T. Outlaw, Jr., "Rehabilitate Racial Whiteness?" in What White Looks Like: African-American Philosophers on the Whiteness Question, George Yancy, ed., 159171 (New York: Routledge, 2004), 168.

8. Bernard R. Boxill, Blacks and Social Justice, revised edition (Lanham, MD: Rowman and Littlefield, 1992): 176-179. Occurrent emotions are conscious or unconscious episodic emotional experiences, often involving pleasure or pain, with associated characteristic physiological changes, such as increased heart rate. Dispositional emotions (or "sentiments") are dispositions to experience occurrent emotions. Standing emotions, by contrast, color one's life by pervasively shaping one's thoughts and behaviors. See William Lyons, Emotion (New York: Cambridge University Press, 1980), 53-57; and Karen Jones, "Emotional Rationality as Practical Rationality" in Cheshire Calhoun, ed., Setting the Moral Compass: Essays by Women Philosophers, 333-52 (New York: Oxford University Press, 2004). 
designation itself (e.g., pride in being Black), on the assumption that racial designations are (or are grounded in) particular sets of somatic features. ${ }^{9}$

Somatic racial pride is individualistic, since it concerns an individual's bodily features, and need not refer to other individuals. It need not refer to socio-political facts that make such features salient, nor to the fact that others possess similar features, nor to the fact (if it is a fact) that there is a racial group to which one belongs in virtue of having these features. Given such individualism, is somatic pride even a type of group pride, let alone a type of racial pride? ${ }^{10}$ Somatic pride becomes racial pride only if one supposes that one's racial identity is at least partly constituted by or grounded in one's physical appearance or when one or more of the following types of pride is blended with it, in a sense to be discussed in $\S 3$.

Second, Boxill identifies a cultural type of racial pride: pride in participating in a set of cultural practices governed by racially distinctive ideals. This type often presupposes a cultural conception of race, such as that defended by the early W.E.B. Du Bois, according to which culture at least partly individuates races. Du Bois's characterization of race suggests that members of a given race are typically committed to living in accordance with particular ideals of life, and that each race has its own distinctive set of ideals, the development and pursuit of which are powerful instruments of the progress of all. He allows for the possibility that individuals will fail to develop or live in accordance with their racial group's ideal, but argues against such cultural assimilation. For instance, he rails against "a servile imitation of Anglo-Saxon culture, ... [rather than] a stalwart originality which shall unswervingly follow Negro ideals."11

9. Thus, Boxill writes, "black pride may simply mean pride in being black, that is, pride in having a black skin and the other physical qualities typical of black people" (ibid., 176); and Zadie Smith, born of a Black father and a White mother, writes, "I cannot honestly say I feel proud to be white and ashamed to be black or proud to be black and ashamed to be white. I find it impossible to experience either pride or shame over accidents of genetics in which I had no active part" (Zadie Smith, "Speaking in Tongues," New York Review of Books, February 26, 2009).

10. One might be particularly inclined to doubt that somatic pride is racial pride if one rejects a biological conception of race. See Yalonda Howze and David Weberman, "On Racial Kinship," Social Theory and Practice 27 (2001): 419-436.

11. W.E.B. Du Bois, "The Conservation of Races" in The Oxford W.E.B. Du Bois Reader, Eric Sundquist, ed. (New York: Oxford University Press, 1996): 38-47; 43. Du Bois provides the following examples of racial ideals: "The English nation stood for constitutional liberty and commercial freedom; the German nation for science and philosophy; the Romance nations stood for literature and art, and the other race groups are striving, each in its own way, to develop for civilization its particular message, its particular ideal, which shall help to guide the world nearer and nearer that perfection of human life for which we all long, that "one far off Divine event"" (42). For discussion of Du Bois's account of race, and a survey of the vast literature debating its meaning and cogency, see Chike Jeffers, "The Cultural Theory of Race: Yet Another Look at Du Bois's "The Conservation of Races," Ethics 123 (2013): 403-26. 
Thus, Du Boisian racial pride is ethnic pride. ${ }^{12}$ Unlike the individualistic somatic conception of racial pride, this cultural conception is both thoroughly social and based in one's agency as a participant in cultural practices. ${ }^{13}$

Two objections confront the Du Boisian conception of racial pride. First, it is doubtful that each race has an individuating set of ideals, let alone a single characteristic "message" or "ideal of life." Second, it is doubtful that all members of any race share or should share any substantive ideals of life. ${ }^{14}$ These objections threaten to undermine the $\mathrm{Du}$ Boisian characterization of race. But the cultural account of racial pride need not invoke this particular conception of race, nor depend upon dubious empirical (or quasidefinitional) claims about the existence of racial ideals. Perhaps, as Laurence Thomas argues, a set of group narratives - that is, "a set of stories which defines values and entirely positive goals, which specifies a set of fixed points of historical significance, and which defines a set of ennobling rituals to be regularly performed"-will do. ${ }^{15}$

Third, Boxill identifies vicarious pride taken in the great achievements of Black individuals. On the one hand, like cultural pride, but unlike somatic pride, vicarious racial pride is essentially a social phenomenon, in two respects. First, as a vicarious emotion, it is essentially interpersonal. Second, as a vicarious racial emotion, the class of potential objects of such pride is typically restricted to co-members of one's racial group. (I return to this restriction below.) On the other hand, unlike cultural racial pride, but like somatic racial pride, the object of vicarious racial pride is not the exercise of one's individual agency. Furthermore, the racial group through which one identifies with the object of one's pride need not be construed culturally or somatically. Thus, one might take this sort of racial pride in individuals from another culture with different bodily features, if one nonetheless thinks of them as co-members of one's racial group.

Lawrence Blum discusses a fourth type of racial pride: pride about one's racial group, understood as a collective agent with achievements of its own. He argues that "Racialized groups are social and historical entities that can engage in pride-worthy behavior and accomplishments - such as resisting oppression and discrimination, persisting in contributing to the larger society in the face of racial obstacles, uniting to defend the rights of others, helping to educate others about the evils of racism and so on."16 One might be proud of one's racial group and its achievements just like one might

12. For a similar treatment of racial pride, see Iris Marion Young, Justice and the Politics of Difference (Princeton: Princeton University Press, 1990), 166.

13. For discussion of the self-recognition that taking pride in such participation requires, see Robert Gooding-Williams, "Race, Multiculturalism and Democracy," Constellations 5 (1998): 18-41.

14. Tommie Shelby advances related objections to the political claim that Black solidarity ought to be founded upon a substantive Black identity in "Foundations of Black Solidarity: Collective Identity or Common Oppression?” Ethics 112 (2002): 231-66.

15. Laurence Thomas, "Group Autonomy and Narrative Identity: Blacks and Jews," in Blacks and Jews: Alliances and Arguments, Paul Berman, ed., (New York: Delacorte Press, 1994): 286-303; 290.

16. Lawrence Blum, "Systemic and individual racism, racialization and antiracist education: A reply to Garcia, Silliman and Levinson," Theory and Research in Education 2 (2004): 49-74; 65. 
be proud of one's country and its achievements. Note, though, that this type of racial pride presupposes controversial claims about the existence of group agents.

Although Blum mentions racial oppression in his discussion, none of the conceptions of racial pride canvassed in this section makes this idea central. That, I shall now argue, is a mistake.

\section{Pride in Resisting Racialized Oppression}

Pride in resisting racialized oppression is, in my view, a fundamental form of racial pride. Perhaps the typical reason why one might take pride in one's racialized bodily appearance, or in one's participation in a set of racialized cultural practices, or in accomplished individual co-members of one's racial group, or in one's racial group as a whole, is that these things - or one's very admiration or celebration of them-represent or embody resistance to oppression. For instance, many common examples of vicarious Black pride cite people who have overcome or undermined racialized oppression - think Fannie Lou Hamer, Malcolm X, Billie Holiday, and Frederick Douglass. And much of the "Black is Beautiful" aesthetic movement is similarly self-consciously political. Mays's pride also cannot easily be explained without appealing to the generations-long resistance to racial oppression that he endorsed and participated in. Thus, pride in resisting racialized oppression often or typically explains why one would experience any of the preceding four forms of pride. ${ }^{17}$

This is not to deny that cultural pride, in particular, is often autonomous from political concerns. Racialized cultural forms certainly have content and value that are independent of political oppression. Even in such cases, though, political oppression and resistance to it can significantly shape such culture and often also the content of the corresponding racial pride.

That resisting racialized oppression is central to racial pride is not surprising, since racialization itself plausibly involves oppressive processes or events. In addition to plausibly shaping the very concept of race, oppression undoubtedly shapes our experience of having a particular racial designation or identity. The idea of oppression is even central to contemporary self-conceptions of people who espouse White pride, who often (erroneously) see themselves as resisting (what they falsely believe to be) oppression of the White race. ${ }^{18}$

However, is feeling pride in resistance to racialized oppression a genuine form of racial pride? Frederick Douglass seems to deny this. This denial, in turn, allows him to ridicule common chauvinistic and parochial race pride while strongly endorsing a racially egalitarian and ecumenical form of pride:

While I have no more reason to be proud of our race than another, I dare say, and I fear no contradiction, that there is no other man in the United States prouder than myself of any great achievement, mental or mechanical, of which any colored man or woman is the author. This is not because I am a colored man, but because I am a man, and because color is treated as a crime by the American

17. Thanks to Rachel Fredericks for suggesting this point. For similar remarks, see Tommie Shelby, We Who Are Dark: The Philosophical Foundations of Black Solidarity (Cambridge: Belknap/Harvard University Press, 2005), 97.

18. See Mitch Berbrier, "The Victim Ideology of White Supremacists and White Separatists in the United States," Sociological Focus 33 (2000): 175-191. 
people. My sentiments at this point originate not in my color, but in a sense of justice common to all right minded men. It is that which gives the sympathy of the crowd to the under dog, no matter what may be his color. ${ }^{19}$

Douglass suggests that what is pride-worthy as regards race, at least in some cases, is resisting or overcoming unjust racial criminalization, and not racial superiority or the advancement of the interests of co-members of one's racial group, as such. Douglass's favored pride is not based "in my color" (a biological feature, or at any rate a feature for which we are not morally responsible). Rather, its origins lie in a capacity for justice that is available to "all right minded men." For these reasons, Douglass insists that such pride is not race pride, which he adamantly rejects. (In what follows, for clarity's sake, I will follow Douglass in using the now somewhat antiquated locution "race pride" to refer specifically to the conception of racial pride that he rejects.)

This is a bit puzzling. Douglass disparages "race pride" while in the same breath strongly endorsing a form of vicarious pride in people of color, the basis of which, however, he says is not racial. Like somatic racial pride, such vicarious pride is not about one's own volitional activity. Therefore, volitional differences between these two forms of pride cannot explain Douglass's different responses to them. ${ }^{20}$ Instead, I infer that Douglass implicitly accepts the restriction mentioned in the discussion of vicarious pride above, namely, that objects of vicarious racial pride must be co-members of one's racialized group. For, Douglass's remark that vicarious pride is not based "in my color" establishes his conclusion that such pride is not race pride only if vicarious race pride must be based "in my color." And vicarious pride is based "in my color" just in case it is restricted to such co-members, perhaps due to the conceit of racial superiority or the assumption of the existence of racial "families" the members of which we should be partial towards.

It follows that, on Douglass's view, pride based in resisting unjust racialized criminalization (or oppression) (a) is not racial pride (all of which he regards as chauvinistic "race pride"), and, I infer, (b) can be elicited by anyone's resistance to any form of racialized oppression, whether or not the proud person shares the same racialized identity or designation as their pride's object (that is, "no matter what may be his color"). As I read him, Douglass welcomes this result, and rejects racial pride in favor of this more ecumenical pride, open to all "right minded men," in resistance to racialized oppression.

Douglass's conception of pride forces us to confront difficulties in the very idea of racial pride. First, it is unclear what we require of a "racial" emotion. I began this section by characterizing pride in resistance to racial oppression as a form of racial pride.

19. Douglass, op. cit., 731.

20. Thus, it would be a serious mistake to attribute to Douglass, as Randall Kennedy does, the view that pride must be based in one's own accomplishments. ("My Race Problem-And Ours," The Atlantic Monthly (May 1997): 55-66.) Indeed, there is no reason to restrict Douglass's line of reasoning to racialized oppression; insofar as gender, nationality, class, or religion are treated as crimes, achievements that resist such criminalization should equally elicit pride in "all right minded men." For further discussion of Kennedy's reading of Douglass, see Bill E. Lawson and Frank M. Kirkland, "Introduction," in Lawson and Kirkland, eds., Frederick Douglass: A Critical Reader, 1-17 (Oxford: Blackwell, 1999). 
Does the fact that such Douglassian pride is not based in (or does not "originate" in) one's own racial designation or identity, and can be about members of different racial groups, disqualify it from being racial pride? Douglass's claim (quoted in $\S 1$ ) that "The whole assumption of race pride is ridiculous" suggests that his answer to this question is "yes." But have we reason to agree?

Second, it is also unclear what we require of pride. Can an emotion about a member of a different social group from one's own, with whom one is unacquainted, count as pride? Pride, unlike, say, admiration, is an emotion felt in response to something that one regards as reflecting well on oneself. So, vicarious pride is typically understood as pride taken in somebody to whom one is partial. Douglass's religiously inspired answer, "that God has made of one blood all nations of men to dwell on all the face of the earth," suggests that he sees himself as being equally partial to all human beings. ${ }^{21}$ But this answer might seem to stretch the bounds of partiality too far, and certainly is not shared by all who have experienced what they would call racial pride.

Let's consider this second question first. One can imagine feeling not just admiration, but pride towards the first person to walk on Mars and the space mission that supports them. Or one might feel pride in watching a gymnast score a perfect 10 on their routine. These events represent outstanding navigation of nature's constraints on the human body. The fact that anyone may take pride in such events, we sometimes find, itself unifies people across social divisions. These examples suggest that mere shared humanity makes intelligible vicarious pride when and, it seems, only when the person one is proud of has achievements that bear upon our evaluating (or reevaluating) human nature and its limits. Such pride may, but need not, involve judgments of species-level group agency (or "species being").

If I am reading him right, then in my view Douglass is correct that succeeding in the face of unjust racialized criminalization is comparable to these high-level achievements. Such success involves navigating society's constraints on both (as Douglass notes) the body and the mind. Unjust criminalization is among the bitterest civic experiences. Often, mere survival under conditions of persecution merits pride. But to not only survive, but thrive under such conditions while openly challenging them - as Douglass and many others have done-is an immense achievement that indeed teaches us about the limits of our human nature. ${ }^{22}$ So, our feelings towards such achievements of individuals with whom we are not acquainted (or otherwise closely related to) can be intelligible as pride.

However, turning now to the first question, in my view there is no reason to deny that such pride is genuinely racial pride, even if feeling it is based in a sense of justice and thus not restricted to racial group co-members. What makes such pride racial pride is not shared group membership, but rather the race-related domain of achievement. Compare: the fact that anyone with a sense of wonder about the universe (not just scientists or explorers) may feel pride in a journey to Mars does not entail that such pride is not scientific or explorational pride. Likewise, the fact that anyone with an appreciation of sport (not just athletes) may feel pride in the perfect performance of a gymnastics routine does not entail that such pride is not athletic pride. Similarly, the fact that anyone

21. Ibid., 731.

22. See Nicholas Buccola, ““'The Human Heart Is a Seat of Constant War”: Frederick Douglass on Human Nature," in Neil Roberts, ed., A Political Companion to Frederick Douglass, 252-282 (Lexington: University of Kentucky Press, 2018); 258. 
with a sense of justice (not just people racialized as Black) may feel pride in Douglass's great anti-racist achievements does not entail that such pride is not racial pride. ${ }^{23}$ Antiracist pride is racial pride.

Douglass's rejection of race pride on ecumenical grounds is directed at partisan conceptions of racial pride, perhaps such as that espoused by Martin Delaney. ${ }^{24}$ Douglass's denial that he has any "more reason to be proud of our race than another" is analogous to the denial on the part of an impartial Olympics sports fan that they have any more reason to be proud of their nation's athletes than another's. Just as the latter denial is clearly compatible with endorsing a more impartial conception of athletic pride, so too is Douglass's denial of partisanship compatible with endorsing an ecumenical conception of racial pride as pride in resistance to racialized oppression. Therefore, Douglass does not contradict himself when he declares his pride in the great achievements of Black men and women, even though he rejects (partisan) race pride. However, if Douglass assumed that racial pride must be partisan — and not just that contemporary advocates of racial pride such as Delaney were partisans - then he was mistaken in doing so.

I should emphasize, in defense of Douglass, that this ecumenical conception of racial pride (like the impartial conception of sports fandom mentioned above) is perhaps uncommon. Many people do seem to understand Black pride, say, as involving a sense of shared Black identity. Moreover, many understand this shared Blackness as itself involving anti-racist resistance. So, the ecumenical conception of racial pride that I have developed from Douglass's text perhaps detaches racial pride from some of its more sociologically paradigmatic instances. ${ }^{25}$ If so, then it is perhaps an emotional analogue to Douglass's highly lauded rhetorical disidentification with certain of his audiences - as in his famous 1852 "Fourth of July Address"- and selective rhetorical invocation of "we." In shifting the domain of racial pride away from racial co-members and towards coworkers pursuing racial justice, Douglass in effect offers a new conception of "We, the People" towards whom we are rightly emotional partial. ${ }^{26}$

23. Thus, I agree with Boxill (op. cit., 177) that Douglass was wrong to assume that racial pride is necessarily chauvinistic. I go further than Boxill in claiming that racial pride may be ecumenical in the sense outlined above. For an account of racial pride that is based in racial group membership and yet does not involve or entail morally objectionable attitudes towards other racial groups, see Jorge J. E. Gracia, "Racism: Negative and Positive?" The Monist 93 (2010): 208-22.

24. Boxill (ibid., 176) also suggests this connection. See, e.g., Martin R. Delany, Principia of Ethnology: The Origin of Races and Color, with an Archeological Compendium of Ethiopian and Egyptian Civilization (Baltimore: Black Classic Press, 1991). For discussion, see Tommie Shelby, "Two Conceptions of Black Nationalism: Martin Delany on the Meaning of Black Political Solidarity," Political Theory 31 (2003): 664-692; and Ronald Sundstrom, "Frederick Douglass's Longing for the End of Race," Philosophia Africana 8 (2005): 143-170.

25. I am grateful to an anonymous reviewer for suggesting that I emphasize this point.

26. As Jason Frank argues, "Douglass refused to simply proclaim a we on behalf of an already constituted political identity, whether the black or the constitutionally organized white people. Douglass spoke on behalf of a people that was not . . yet" ("Staging Dissensus: Frederick Douglass and 'We the People,"' in Constituent Moments: Enacting the People in Postrevolutionary America (Durham: Duke University Press, 2010), 209-236; 217; emphasis added, ellipses in original). For 
This ecumenical account explains an important asymmetry between White pride and Black pride. For the achievements of White individuals are not typically of this racial kind (though they may well represent social achievements of other kinds). Overcoming or resisting racialization is irrelevant to J.S. Bach's achievements - if anything, Bach's racialized status illicitly provided him with resources for his achievements, not obstacles to overcome. So, feeling racial pride towards Bach would be absurd (though there may be some sort of pride available toward Bach's achievements), in a way that feeling it towards Billie Holliday might not be.

The five types of racial pride described in $\S 2$ and the present section are rarely distinguished, perhaps because people who have the sentiment of racial pride are often disposed to experience instances of all five types of the emotion, which tend to blend into each other and into other emotions. So, I conclude this section by briefly considering two versions of this dispositional emotion and the central role that Douglassian racial pride often plays in both.

One version is the disposition to feel several sorts of different episodes of racial pride. This seems to fit the case of Willie Mays, who described his experience of pride in terms of vicarious racial pride in Barack Obama, as well as perhaps both (American or Black American) group pride and individual pride in resisting racial oppression.

"Racial pride" also can refer to a broader disposition to experience shame, hope, fear, anger, humor, and love, as well as many sorts of different episodes of pride, among other emotions. ${ }^{27}$ Being disposed to experience somatic racial pride and pride in resisting racial oppression may also, by virtue of the same disposition, dispose one to experience anger at racial oppression, shame at the failings of fellow members of one's racial group, and love of these fellow members in spite of their failings. Crucially, dispositional emotions are characterized in terms of which occurrent emotions one both does and does not experience. Thus, it is sometimes the dispositional emotion that is referred to when racial pride is construed as refusing to be ashamed of one's racial identity.

Racial pride is often dispositional, and the disposition often or typically includes occurrent pride in resisting racial oppression, either vicariously or directly. The judgments involved in such occurrent pride also often help to structure the disposition of which it is a part. Universal judgments about the pride-worthiness of resisting racialized oppression are often joined with particular judgments about which people, events, qualities, or states of affairs resist it (or reflect such resistance). This is the sense in which resisting racial oppression is often or typically central or fundamental to feeling racial pride, and the sense in which somatic, cultural, group, and vicarious pride often blend together.

I assume that the evaluative status of dispositional emotions depends upon the evaluative status of the occurrent emotions that the dispositional emotion disposes one to experience. Therefore, I limit the next section's discussion of evaluating racial pride to evaluations of occurrent emotions.

further discussion of the rhetoric of dissociation and identity in Douglass, see Kirt H. Wilson, "Political Paradoxes and the Black Jeremiad: Frederick Douglass's Immanent Theory of Rhetorical Protest," Howard Journal of Communications 29 (2018): 243257.

27. On dispositional pride, see Kristján Kristjánsson, "Pridefulness," Journal of Value Inquiry 35 (2001): 165-178. 


\section{Proper Pride}

In this section I consider the extent to which racial pride is appropriate: in particular, whether racial pride ever accurately represents its intentional object as pride-worthy (§4.1), and whether feeling racial pride is ever valuable $(\S 4.2)$.

\subsection{Representational Correctness}

To assess whether racial pride ever accurately represents its object (i.e., is "fitting"), we need a general account of how pride represents its object. Each type of emotion presents its objects as having certain properties: roughly, fear represents its objects as dangerous, anger as having done something wrong, hope as in some way good and realizable. I will assume that pride represents oneself, in virtue of the object of pride, to be living in accordance with one's worthy personal ideals, which are norms about what sort of character, commitments, relationships, and attitudes one should have. ${ }^{28}$

Assuming that pride involves such a judgment, a token of pride is fitting just when:

(1) The object of pride exists; ${ }^{29}$

(2) The object of pride provides evidence that one is living in accordance with some of one's personal ideals; and

(3) The relevant personal ideals are worthy of one's adoption or pursuit.

Fitting pride requires that there is in fact an object of pride that in fact provides evidence that one is living in accordance with personal ideals that are in fact worthy. Can any of the five forms of racial pride surveyed above be fitting?

Somatic pride has often been charged with being unfitting. Douglass argues that bodily features like skin color are not the achievements that pride represents them as being:

Our race and color are not of our own choosing. We have no volition in the case one way or another. The only excuse for pride in individuals or races is the fact of their own achievements. Our color is the gift of the Almighty. We should neither be proud of it nor ashamed of it. But we may well enough be proud or ashamed when we have ourselves achieved success or have failed of success. If the sun has curled our hair and tanned our skin let the sun be proud of its achievement, for we have done nothing for it one way or the other. ${ }^{30}$

28. For a defense of this account see my "Why Are You Proud of That? Cognitivism About "Possessive" Emotions," Southwest Philosophy Review (forthcoming); for further discussion, see Antti Kauppinen, "Pride, Achievement, and Purpose," in The Moral Psychology of Pride, J. Carter and E. Gordon, eds. (London: Rowman and Littlefield, 2017): 169-190.

29. The wording of this condition is shorthand for whatever success conditions are appropriate for the emotion's type of intentional object: individuals or groups (e.g., my country) must exist; propositions (e.g., I won the race) must be true; events (e.g., my achievement) must have occurred; properties of individuals (e.g., my house's beauty) must be predicated of those individuals.

30. Douglass, op. cit., 730. For a similar argument, following Douglass, see Kennedy, op. cit. I take Douglass's claim that one's achievements are "the only excuse for pride" to 
Let us reconstruct the argument in the terms of the personal ideals-based account of pride, as follows:

(P1) Pride is fitting only when the object of pride provides evidence that one is living in accordance with worthy personal ideals.

(P2) Only achievements can provide evidence that one is living in accordance with worthy personal ideals.

(P3) The object of racial pride is always some set of racialized bodily features.

(P4) Racialized bodily features are never achievements.

(C) So, racial pride is never fitting.

Douglass is correct that regarding genetically determined somatic features in themselves as achievements would be absurd. ${ }^{31}$ So, (P4) is true. However, as we have seen, racialized bodily features are only one of many possible sorts of objects of racial pride. Thus, (P3) is false. We may modify Douglass's argument to restrict its conclusion to somatic racial pride, but this modification still leaves the argument open to objection on the grounds that $(\mathrm{P} 2)$ is false, as follows.

Suppose that slogans like "Black is Beautiful!" are injunctions to feel pride in one's racialized physical appearance. Suppose further that the relevant personal ideal is physical beauty, which may be met just by the fact that one is Black. If so, it is possible to accord with this aesthetic personal ideal without achieving anything through one's agency. As Boxill remarks, "If, as Douglass observed, 'Our color is the gift of the Almighty,' race pride may simply be a rejoicing in the gift of the Almighty." 32

One might doubt that any ideal that is so easy to accord with can be worthy in the sense required for one's pride to be accurate. Yet race-related aesthetic ideals can be worthy insofar as being comfortable with, and taking pleasure in, one's embodiment can make one's life more meaningful. Showing that aesthetic ideals make life more meaningful requires a full-length treatment, which I cannot hope to provide here. But that is where the argument must take place, and the burden of proof lies with Douglass, whose conclusion conflicts with common sense. 33

Consider now, in turn, the other sorts of racial pride. Cultural-racial pride may accurately represent its object: the object of pride, whether pursuing racial ideals or developing racial narratives, may in fact take place; such activity can in fact provide evidence that one is living in accordance with some of one's personal ideals; and such

be about pride's fittingness, or what property an object must have in order for pride to accurately represent it. Howze and Weberman, op. cit., instead take Kennedy's Douglassian argument to concern the rationality of feeling racial pride.

31. Though when it comes to beauty norms, matters are rarely so simple. Achieving a "natural look" often requires considerable time, money, and effort. Even simply resisting the social or economic pressures to chemically alter one's hair texture or skin color, or surgically alter the epicanthic folds of one's eyelids, may involve considerable strain (psychological, financial, or otherwise). Thanks to Rachel Fredericks and Elizabeth Scarbrough for discussion on this point.

32. Op. cit., 177.

33. See Paul Taylor, Black is Beautiful: A Philosophy of Black Aesthetics (Oxford: Wiley-Blackwell, 2016). 
personal ideals may in fact be worthy. The ideals, which will differ from group to group, may involve norms about humor, body language, and other conversational practices; and religious, artistic, political, romantic, familial, and culinary practices, among others. And endorsement of them may enhance trust and community within the racial group. Provided that the relevant community does not have immoral ends, being a contributing member of a community is a worthy ideal, whether the community is geographically, politically, racially, or otherwise defined. So, such cultural activity can also be pride-worthy.

Vicarious racial pride differs from the first two types insofar as it seems to be about another person. I say "seems to be" because it is, plausibly, a conceptual truth about pride that it always concerns the self. This reflexivity distinguishes pride from other-regarding attitudes like admiration. ${ }^{34}$ So purported instances of pride in another person are either misdescribed as pride or are covertly about the self. Yet if such pride concerns the self, it is obscure how another's activity could establish anything about whether one is living in accordance with one's personal ideals.

One answer is that pride in another's activity could be fitting if one enabled it, as perhaps in the case of Willie Mays helping to enable Obama's presidency. However, this would not render pride in one's ancestors (or others whose success one did not enable) fitting. A second answer is that, in feeling vicarious pride, one empathetically identifies (in some sense) with the other person. ${ }^{35}$ On this account, experiencing pride in another's accomplishments is analogous to feeling embarrassed by another's social gaffe. In both cases one's judgment about the activity of another person generates, via empathetic identification, an emotional experience about oneself. Such identification can make life more meaningful by structuring one's agency and helping to make one the person one is. As such, personal ideals that involve empathetic identification of this sort may be worthy of one's commitment. 36

A third answer appeals to the group conception of racial pride, discussed by Blum. Group pride is derivatively about oneself and also about any other members of one's racial group. For example, one might, as a Black American today, take pride in the leading role that Black Americans as a group played in defeating the Confederacy. If so, then one takes one's membership in the same pride-worthy group to reflect well upon oneself. This sort of pride accurately represents its object insofar as membership in any pride-worthy group is itself pride-worthy.

Thus, vicarious racial pride may involve judgments about one's contribution to another's achievement or common group membership, or empathetic links between self and other. Such judgments or empathetic links, if appropriate, render pride accurate.

The final type of racial pride, pride in resistance to racial oppression, is most obviously a fitting type of pride. I assume that paradigmatic examples of resistance to oppression include protest against injustice, assistance to victims of oppression, legislative or institutional work to end oppression and, most generally, the steadfast

34. Hume argues, in Chapters 1 and 2 of Book 2 of his Treatise, that such reflexivity distinguishes pride from love. For a contrary view, see Bennett Helm, Love, Friendship, and the Self: Intimate Identification and the Sociality of Persons (New York: Oxford University Press, 2010).

35. See Joel Feinberg, "Collective Responsibility," The Journal of Philosophy 65 (1968): 674-688.

36. See my "Pride and Moral Responsibility," Ratio 30 (2017): 181-196. 
pursuit of the interests of oppressed people, possibly including oneself. ${ }^{37}$ Each of these kinds of achievements is worthy of pride. Such feats are also well suited for vicarious and group racial pride, since one's resistance to this oppression plausibly contributes to others' resistance to similar oppression, and vice versa. Moreover, given that all oppression is group-based, resistance to racial oppression is always potentially a group project.

If the very existence of racial groups depends upon racialized oppression (and not solely upon some biological or cultural property of individuals), then resisting racialized oppression will be among the most pride-worthy accomplishments, qua race, of any racialized individual or group. For, this political view of race (together with uncontroversial egalitarian moral claims) entails that one, if not the, primary worthy goal with respect to race is eliminating racialized oppression. Moreover, if race reduces at least partly to such political facts, then aesthetic, ethical, and political ideals are worthy as racial ideals primarily insofar as they are oriented towards illuminating and ending, or at least enabling people to survive under, racialized oppression. These ideals can survive the end of racialization; that end would merely eliminate their racial aspect. (Compare presently existing aesthetic ideals relating to Jewish humor, much of which derides antiSemitism with various degrees of subtlety, and which was thoroughly racialized in the early $20^{\text {th }}$ Century but is no longer widely regarded as racial.)

So, racial pride can be fitting. However, this fact does little to buttress claims about the value of experiencing racial pride. By analogy, the fact that something of yours is envious would not entail that my envying you would be beneficial or otherwise valuable. Let us now consider whether pride is like envy in this respect.

\subsection{Value}

Concern about the value, or lack thereof, of feeling racial pride drives much of our interest in it. So, I will critically evaluate two arguments for the claim that experiencing racial pride can be extrinsically valuable: first, the individualistic argument that pride is valuable because it increases individual self-esteem or well-being; and second, the collective argument that pride is valuable because it promotes or helps to constitute solidarity against racial oppression.

Note first, however, that experiencing fitting racial pride is itself sometimes intrinsically valuable. For, taking pleasure in what is intrinsically good is intrinsically valuable. ${ }^{38}$ Since some objects of racial pride (possibly including the beauty of one's racialized physical features, one's Du Boisian racial culture, the achievements of members of one's racial group or of the racial group itself, or resistance to racialized oppression) are intrinsically good, and since pride typically involves pleasure, feeling fitting pride in these intrinsically valuable objects for their own sakes is also intrinsically valuable.

However, discussion of racial pride's value typically concerns its extrinsic and, more specifically, instrumental value. For example, one recent meta-analysis of 38 psychological studies concludes, "it is clear that higher levels of racial pride are linked to

37. See Ann Cudd, Analyzing Oppression (New York: Oxford University Press, 2006), especially Chapters 7 and 8.

38. Thomas Hurka, Virtue, Vice, and Value (New York: Oxford University Press, 2003), 13. 
positive outcomes for African American youth." 39 The authors understand such pride to be positive "feelings about their African and African American heritage, culture and phenotypic features." 40 The positive outcomes that are linked to such feelings include academic achievement, self-esteem, and mental health (especially the reduced incidence of depression).

Which type of racial pride is most valuable in this regard? Boxill argues that vicarious racial pride "best enhances black self-esteem." 41 For, more than somatic or cultural pride, vicarious pride directly challenges the racist judgment that Black people are incapable of significant accomplishment. Boxill, thus, rightly appreciates the subversive quality of racial pride.

The self-esteem-based argument faces three limitations of scope or prima facie objections. First, even if experiencing racial pride increases self-esteem, it is unclear whether the problem that Boxill concentrates on still exists in all oppressed racial groups. Research suggests that, since the early 1980s, Black individuals have consistently reported the highest levels of self-esteem of any racial group in the United States. ${ }^{42}$

Second, even if enhancing self-esteem is desirable, there is no reason to believe that feeling racial pride in the achievements of other members of one's maligned racial group opposes racist judgments any more effectively than does the mere belief that those racist judgments are false. So, the self-esteem-based argument no more justifies inculcating the feeling of racial pride than it justifies inculcating the belief that members of one's racial group are capable of significant achievement.

Third, vicarious racial pride might not help one to psychologically confront a (purportedly) primary source of one's race-related deficit of self-esteem, namely racial oppression. Consider Boxill's example of vicarious Black pride towards St. Augustine. That Augustine was Black indeed puts to rest the claim that Black people are incapable of significant achievement. However, such individualistic examples of racial pride, especially examples of pride in individuals who never needed to overcome racial oppression as we know it, do not address self-esteem deficiencies based in despair about one's prospects for overcoming racial oppression. This example, in differing from so many other common examples of objects of racial pride, such as Cesar Chavez and Sojourner Truth, highlights by omission the centrality of resistance to racial oppression to common examples of racial pride. 43

39. Corinn A. Elmore, Jelani Mandara, and Lauren Gray, "The Effects of Racial Identity on African American Youth Well-Being," in African American Identity: Racial and Cultural Dimensions of the Black Experience, J.M. Sullivan and A.M. Esmail, eds., (New York: Lexington Books, 2012), 89-124; 115-116.

40. Ibid., 96.

41. Boxill, op. cit., 178.

42. See Jean M. Twenge and Jennifer Crocker, "Race and Self-Esteem: Meta-Analyses Comparing Whites, Blacks, Hispanics, Asians, and American Indians and Comment on Gray-Little and Hafdahl (2000)," Psychological Bulletin 128 (2002): 371-408.

43. For a related objection, see Michael Eric Dyson, Pride (New York: Oxford University Press, 2006), especially Chapter 4. Of course, Black pride in people who did not face racialized oppression may yet have indirect political value. See, for example, Du Bois's endorsement of the "just pride" taken in Nefertari, Askia, and Moshesh, in his 
Given these three prima facie objections to the individualistic self-esteem rationale for feeling vicarious pride, I suggest that it be supplemented with or replaced by an appeal to the collective value of feeling racial pride. Feeling pride in one's own and others' resistance to racialized oppression plausibly promotes or helps to constitute socially valuable relations or achievements. Such Douglassian racial pride, including perhaps pride in Sojourner Truth but not pride in Augustine, is, plausibly, necessary for sustaining effective large-scale resistance to oppression. For, it partly constitutes the identification that group members in a state of political solidarity have with each other. ${ }^{44}$ In this respect, as Douglass remarks about the desire to perpetuate illustrious examples of excellence joined with pious gratitude, "It imparts dignity to human nature, and makes the lives of the great and good, of all ages, contemporary with our own, and co-workers with us." 45

Moreover, unlike Boxill's account of the anti-racist value of racial pride, this account need not invoke a biological conception of race. Thus, if such conceptions of race are false, then my account avoids a version of Douglass's objection that such pride is "a positive evil. It is building on a false foundation." 46 Pride in resistance to racialized oppression may instead invoke a social constructionist account of race according to which race is understood in terms of racialized oppression. ${ }^{47}$ Such pride is about resisting or overcoming some of the very forces that objectionably bind racial groups together in the first place. ${ }^{48}$ Racial pride of this sort is valuable to all, even to those who do not suffer from a deficit of self-esteem, since it is an anti-racist emotion with the potential to generate appropriate understanding, desires, and behavior in the context of racialized oppression. Such pride plausibly helps to focus attention upon the goal of eliminating such oppression, and to generate productive habits of remembrance that sustain one's anti-racist identity and efforts. ${ }^{49}$ The political value of this attentiveness is absent from racial pride in objects that are unrelated to oppression.

Finally, and again, this account explains one dimension of the moral asymmetry between White pride and the racial pride felt by people of color. The latter is often a

1933 essay, "On Being Ashamed of Oneself: An Essay on Race Pride," in W.E.B. Du Bois: A Reader, Lewis, ed., (New York: Holt, 1995): 76-80.

44. See Feinberg, op. cit.; Shelby (op. cit., 2005, 68); and Dyson (ibid., 84).

45. Frederick Douglass, "In Honor of Asa S. Wing," in The Frederick Douglass Papers, Series 1, Vol. 3, 107-114 (New Haven: Yale University Press, 1992), 109. For discussion see Buccola, op. cit.

46. "The Nation's Problem," 730.

47. As Sally Haslanger notes, this conception of race undermines the view that race is a positive social identity. ("Gender and Race: (What) Are They? (What) Do We Want Them To Be?” Nous 34 (2000): 31-55; 48.) So, an account of racial pride founded upon this conception of race might seem incongruous. However, even if one lacks grounds for pride in the mere fact of being Black (say), one may still have grounds for racial pride in one's own and others' resistance against racialized oppression.

48. This claim is compatible with there being unobjectionable sources of race-based community.

49. See Terrance MacMullan, The Habits of Whiteness: A Pragmatist Reconstruction (Indiana University Press, 2009), especially Part 4. 
celebration of resistance to racialized oppression; White pride, as commonly construed, completely lacks this content, and often actually celebrates racial oppression. Thus, as they are commonly construed, Black pride and White pride embody opposed evaluations of racialized oppression. Insofar as White pride involves taking pleasure in intrinsically bad facts or relations (which it seems to do in many, if not all, actual cases), it is both intrinsically bad (for the reasons given at the start of this subsection) and also likely to be extrinsically bad.

\section{Anti-Racist Pride for White People?}

But perhaps there is a type of racial pride available to White people besides the common construal of it.50 Indeed, this is so, if, as I have argued, Douglassian ecumenical racial pride in resisting racialized oppression is available and valuable to all persons. This section sketches what such pride might look like.

Just as people of color can do, a White person who manages to achieve "a sense of justice common to all right minded men" can experience Douglassian vicarious racial pride in anti-racist resistance efforts. For, as Douglass emphasizes, such pride, now detached from racial group co-membership, is grounded in shared humanity and the universal value of challenging or overcoming unjust racial criminalization.

Although I (following Douglass and Boxill) have focused on the achievements of Black people, Douglass's formulation allows that, though White people are not subjected to racial oppression, they may nonetheless challenge the crime of unjust racialization in a pride-worthy way. Pride taken in being a so-called "White race traitor" might be fitting and valuable, insofar as that emotion, properly construed, generates effective antioppressive desires, emotion, cognition, and/or behavior.

To be clear, such pride differs from pride in one's Whiteness, one's White identity, one's "White culture," or in having and exercising White privilege. As Samantha Vice notes, "It would be inappropriate to value a history of oppression, a system of privilege or whitely habits, and for many of the world's people, this is what white stands for." 51 Fitting pride in White identity would therefore require "refashioning" such identity, so that the history of White oppression no longer overshadowed whatever distinctively White cultural values or accomplishments there may be. Yet the prospects of such a refashioning are bleak.52 Therefore, I agree with Vice that there is little or no reason to believe that being White in itself could be pride-worthy. My Douglassian proposal is even compatible with Vice's claim that the Whiteness of one's self is worthy instead of shame or guilt.

50. For a discussion of the prospects of reforming White pride, see MacMullan, ibid.; Samantha Vice, op. cit.; Shannon Sullivan, "Whiteness as Wise Provincialism: Royce and the Rehabilitation of a Racial Category," Transactions of the Charles S. Peirce Society 44 (2008): 236-262; Shannon Sullivan, "Transforming Whiteness with Roycean Loyalty: A Pragmatist Feminist Account," in Contemporary Feminist Pragmatism, ed. Maurice Hamington and Celia Bardwell-Jones, 19-41 (New York: Routledge, 2012); Andrew Pierce, "Reconstructing Race: A Discourse-Theoretical Approach to a Normative Politics of Identity," Philosophical Forum 43 (2012): 2749; and Lucius T. Outlaw, op. cit.

51. Vice, ibid., 197.

52. For a useful recent treatment that arrives at a contrary view, see Linda Martín Alcoff, The Future of Whiteness (Malden: Polity, 2015). 
The Douglassian racial pride available to White people concerns actions, not selves. It is about discrete achievements, not habits or dispositions. It is about defying racial oppression, not adopting or perpetuating "White culture." It is thus, in Douglassian spirit, about the anti-racist or counter-racist achievements of humanity, and not White achievements qua White.

There are numerous important objections and counter-arguments to the claims that (a) racial pride about a White person's anti-racist achievement is sometimes fitting and (b) a White person's feeling such pride is sometimes morally unobjectionable. Let us consider three. One might argue, first, that this is not really racial pride, if the pride is not taken qua Whiteness. Note, however, that in cases of Black pride the emotion need not (and in the case of Douglassian racial pride, cannot) be taken qua Blackness. Indeed, if RACE is a sociopolitical concept, where being Black involves being racially oppressed, then some instances of Black pride are about defying one's Blackness. Other instances might be about non-racially identified anti-racist achievement. ${ }^{53}$ Likewise, with respect to Douglassian racial pride available to, or about, White people who defy their White racial role. Pride in John Brown's raid, say, could be such racial pride.

Second, one might object that one cannot take pride in the anti-racist activities of a White person, if Vice is right that Whites generally or always have racially vicious character traits. For, an anti-racist act is pride-worthy only if it is fully virtuous; and as Aristotle argues, an act can be fully virtuous only if it expresses or is caused by virtuous character. However, I deny this Aristotelian claim. Having a stable virtuous disposition is not necessary for occasionally acting virtuously. Virtuous actions are motivated by considerations that, in the given set of circumstances, characteristically motivate virtuous persons; and such considerations can on occasion motivate even vicious persons.

One might object, instead, that White anti-racist activity is never pride-worthy, since it is always merely discharging moral duties. Refusing to act wrongly or engage in blameworthy activity is never supererogatory, i.e., beyond the call of duty. So, refusing to be complicit in racial oppression is merely responding to the call of duty, not exceeding it. It is the least one can do. Yet, one might think, pride-worthy moral or political accomplishment must be supererogatory. Otherwise, as Vice worries, "the bar may be set too low if attaining basic decency and fairness becomes a moral achievement worthy of pride." 54 This objection to the fittingness of racial pride towards a White person's antiracist activities has force. It is true, as Vice argues, that much anti-racist White activity is not supererogatory. ${ }^{55}$ Furthermore, let us grant that pride-worthy moral accomplishment must be supererogatory. (One wonders, though, whether the pride-worthy anti-racist activity of people of color must, in fact, be supererogatory. ${ }^{56}$ ) Nonetheless, anti-racist

53. I am grateful to an anonymous reader for posing the question, whether anti-racist resistance as a Black person might be more valuable than anti-racist resistance that lacks any sense of racial identification. I have no answer to this important question; answering it would require developing an account of the nature and value of racial identification. However, if, as Vice argues, White identity is shameful, then the only reasonable mode of anti-racist pride for White people may be the Douglassian sort.

54. Vice, op. cit., 203.

55. Vice, ibid., 202-203.

56. I am grateful to an anonymous reader for suggesting this point. 
White achievements that involve significant risk of severe harm are plausibly supererogatory and thus pride-worthy.

I mention six examples to illustrate the point. I have alluded already to the famous case of John Brown. Attempting to free kidnapped and enslaved people by force, not only at Harper's Ferry but also in Kansas, Missouri, and elsewhere, and then submitting to execution upon capture, as he did, is plausibly supererogatory. Even if such force was impermissible, though, Brown's years of organizing work with the Underground Railroad and other non-violent activities were plausibly supererogatory. Consider next Silas Soule, a White Union captain and former volunteer in the Underground Railroad who in 1864 not only refused to follow orders to kill Cheyenne and Arapaho people in the Sand Creek Massacre, but then testified publicly against the colonel who commanded the assault. Soule's act of courage was a possible cause of his being shot and killed shortly thereafter, at the age of 26.57 Consider Jessie Ames, who crafted a feminist campaign against lynching partly by insisting, as a Southern White woman, that Black men were not the threats to Southern White womanhood that racist Whites often took them to be. Ames founded the Association of Southern Women for the Prevention of Lynching in 1930.58 Consider Helen Hunt Jackson, a White scholar and activist who authored the 1881 critique of U.S. policy towards Native Americans, A Century of Dishonor, and the 1884 bestselling novel, Ramona, an exposé of injustice towards Native Americans. Jackson later served as an agent of the U.S. Interior Department, working (though with little success) to identify and secure claims of Native Americans in California.59 Or consider the journalist, Anne Braden, who in 1954 along with her husband, Carl, bought a Louisville home on behalf of the Wade family who was denied purchase due to a restrictive covenant. Braden also organized to desegregate a hospital in Kentucky in 1950, and organized throughout her life, starting in the 1950s, to protect the rights of prisoners. ${ }^{60}$ Finally, consider Edward Coles, who in 1814 initiated a fascinating correspondence with Thomas Jefferson, pressing him to publicly advocate for abolition. Five years later, Coles fled Virginia to free the 19 enslaved people whom he "inherited," providing each family with 160 acres of land in Illinois. Three years later, Coles became the second governor of Illinois, and worked to completely eradicate slavery from that state. 61

57. There is no full-length study of Soule's life. See "The Life of Silas Soule," U.S. National Parks Service <https://www.nps.gov/sand/learn/historyculture/the-life-ofsilas-soule.htm>.

58. Jacquelyn Dowd Hall, Revolt Against Chivalry: Jessie Daniel Ames and the Women's Campaign Against Lynching (New York: Columbia University Press, 1993 [Revised Edition]).

59. Valerie Sherer Mathes, Helen Hunt Jackson and Her Indian Reform Legacy (Austin: University of Texas Press, 1990).

60. Catherine Fosl, Subversive Southerner: Anne Braden and the Struggle for Racial Justice in the Cold War South, Foreword by Angela Y. Davis (Palgrave MacMillon, 2002).

61. See Kurt E. Leichtle and Bruce G. Carveth, Crusade Against Slavery: Edward Coles, Pioneer of Freedom (Southern Illinois University Press, 2011); and Suzanne Cooper Guasco, Confronting Slavery: Edward Coles and the Rise of Antislavery Politics in Nineteenth-Century America (Northern Illinois University Press, 2013). 
None of these figures is entirely unobjectionable. But some of their actions are supererogatory pride-worthy racial achievements. I submit that it is lamentable and, indeed, shameful that few of these figures' efforts are widely known or celebrated by White people. Taking pride in such efforts would help redirect White attention to both White people's perpetuation of racial oppression and their resistance to it. Inculcating such pride may also send the message that White people should use their persistent and unjustified racial position in pride-worthy ways, and celebrate supererogatory resistance to oppression they are customarily called on to help inflict.

Various vicious habits do need to be guarded against, if such racial pride is to be morally appropriate. For example, "white savior" narratives are generally, and notoriously, morally objectionable, given the context of White oppression and the pervasiveness of stereotypes about the inefficacy of people of color. White people therefore must guard against the habit of regarding the objects of racial pride (vicarious or self-directed) as "white saviors" who rescue "helpless" people of color. Moreover, one risk of such racial pride is foregrounding, yet again, the achievements of White people in the historical record at the cost of backgrounding the achievements of people of color. This concern provides a reason to celebrate White people who, as Du Bois said of John Brown, work with people of color, not simply for them. ${ }^{62}$ Furthermore, there is a risk that taking first-personal or vicarious pride in the achievements of the past will lead Whites to complacency or ignorance about contemporary forms of oppression that may be more subtle, and will prevent them from considering the possibility that further efforts at personal and political improvement are needed. Thus, precautionary measures should be taken, such as setting short-, medium-, and long-term goals for one's own anti-racist efforts; integrating such efforts into many or all of one's projects; finding contemporaries to stand in solidarity with and to hold one accountable; and developing habits that regularly bring one into contact with people from different social classes or groups who will share their experiences of ongoing racialized oppression. 63

To reiterate, such considerations should not be taken to justify pride in Whiteness itself. The point is not to exonerate Whites of their crimes, to celebrate the alleged commitment of "White culture" to norms of justice, to prove that Whites are good "allies," or to portray the allegedly self-correcting nature of White institutions. Rather, the point (perhaps among others) is to reorient oneself and ourselves away from the norms and assumptions of White supremacy. Racial pride thus construed is what Alison Jagger calls an "outlaw emotion": "Outlaw emotions are distinguished by their incompatibility with the dominant perceptions and values." For example, "pride becomes feminist pride when it is evoked by realizing that a certain person's achievement was possible only because that individual overcame specifically gendered obstacles to success."64 Unlike people of color, White people do not generally face racialized obstacles to success. On the contrary. Yet, the above (purported) examples of prideworthy White anti-racist achievement can reorient White people to raise the bar on what they themselves might achieve, and thereby motivate them to deliver at least what they

62. W.E.B. Du Bois, John Brown (Philadelphia: Jacobs and Company, 1909), 7.

63. I am grateful to an anonymous reader for suggesting this concern, and to Rachel Fredericks for brainstorming with me about possible precautionary strategies.

64. Alison Jaggar, "Love and Knowledge: Emotions in Feminist Epistemology," in Gender, Body, Knowledge: Feminist Reconstruction of Being and Knowing, Jaggar and Bordo, eds. (Rutgers University Press, 1989): 145-171; 160. 
owe to others and perhaps more. It can also help them to identify the "dominant perceptions and values" that pose racialized psychological and social obstacles to their own decency and justice, and to appreciate the different political responses available to Whites vis-à-vis racial oppression. ${ }^{65}$

Finally, one might object to an implication of my Douglassian claim that vicarious racial pride's object need not be a co-member of one's racial group. One might worry that it is objectionable appropriation for White people to feel racial pride about the achievements of people of color in resisting racial oppression perpetuated by White people. Even non-racial vicarious pride often seems objectionable on similar grounds: one might, say, take exception to the fact that one's abusive family members are proud of one's achievements, and reasonably ask, "Who are you to take pride in my accomplishment?" This worry is greatly compounded when somebody else takes vicarious pride in one's resistance to the very oppression in which they are complicit. I agree that complicity in racial oppression can make such pride not only morally objectionable, but also unfitting. For, such complicity can undermine the second condition of pride's accuracy, that the object of pride reflects one's living in accordance with one's ideals. The matter may be different, though, when one makes substantial efforts to extricate oneself from this complicity and to create what Douglass called a "composite nationality."66 If such efforts satisfy reasonable demands, which I suspect is quite difficult to do, then it is reasonable to see oneself as taking part in anti-racist efforts and as sharing anti-racist ideals with those of whom one is proud, even if complete extrication from complicity is impossible. So, vicarious pride in anti-racist achievement is unavailable to many, but perhaps not all, White people who remain complicit in racialized oppression. I leave it to others to determine which White people, if any, are, as a result of their substantial efforts to extricate themselves from such complicity, merely unavoidably complicit.

\section{Conclusion}

I have focused this essay on establishing two main theses about the emotion of racial pride. First, resistance to racialized oppression is central to racial pride; and second, some instances of racial pride, including possibly some few instances of anti-racist pride felt by Whites, are both accurate and valuable, especially insofar as they have collective political value.

One upshot is that two new responses are available to the frequently heard, and typically hostile and bad faith, White demand that, if there is to be a Black History Month, there should be a White History Month to encourage analogous racial pride in

65. This politically oriented proposal complements MacMullan's culturally oriented proposal that whites take pride in their ethnic (e.g., Scots-Irish) traditions as a way of "decoloniz[ing] the[ir] minds ..., by asserting the differences within whiteness" (op. cit., 202).

66. Frederick Douglass, "Our Composite Nationality: An Address Delivered in Boston, Massachusetts, on 7 December 1869," in The Frederick Douglass Papers, Series 1, Vol. 4 (New Haven: Yale University Press, 1992), 240-159. For discussion, see Julie Husband, "Multicultural American Exceptionalism in the Speeches of Frederick Douglass and Barack Obama," Howard Journal of Communications 29 (2018): 225242. For discussion of the civic context of racism, see my "Racism as Civic Vice," Ethics (forthcoming). 
Whites. The common response that every (or nearly every) month is already, in effect, White History Month is correct so far as it goes: historical attention in the United States, including in U.S. philosophy departments, remains until this day largely riveted to the history of Europeans and their American descendants. But, although the unreasonable demand mentioned above deserves no further response, it is also true that Whites tend to pay insufficient attention to anti-racist achievements, including those of White antiracists. Much of what Douglass said about John Brown applies to at least some of these other White people as well: "Like the great and good of all ages - the men born in advance of their times, the men whose bleeding footprints attest the immense cost of reform, and show us the long and dreary spaces, between the luminous points in the progress of mankind, - this our noblest American hero must wait the polishing wheels of after-coming centuries to make his glory more manifest, and his worth more generally acknowledged." 67

So, first, we may add in response that Whites who have made substantial efforts to extricate themselves from complicity in continuing racial oppression are already free to take pride, in a Douglassian spirit reflecting "a sense of justice common to all right minded men," in the anti-racist achievements of people of color. Second, if the first response fails to satisfy White chauvinists, as I assume it would, we should agree to consider establishing a White History Month, with a catch: the activities involved therein must focus on celebrating anti-racist White achievements, serving as the polishing wheels of these neglected but pride-worthy achievements. Proposing such a memorial in a way that conveys an egalitarian public message would be rhetorically difficult, and attempting to do so in the current political climate may be ill advised. But I believe that doing so is worth considering, for two reasons. First, this response to misguided hostility against Black pride redirects attention to a central basis of it, namely resistance to racial oppression perpetrated by White people. Second, White anti-racists' achievements of the sort enumerated above should, as already explained, be more widely known and celebrated.

Throughout this paper, I have emphasized the multifariousness of both racial pride and our evaluations of such pride. To summarize, there are: at least five types of occurrent racial pride; two types of dispositional racial pride; two dimensions of evaluation of racial pride (fittingness and value); and several standards of value, intrinsic and extrinsic, against which one might evaluate racial pride, including prudential, aesthetic, and political value.

I conclude by observing that most of the philosophical literature on racial pride (this essay included) notably omits discussion of yet another variety of racial pride: the character trait of racial pride. ${ }^{68}$ The character trait, unlike the emotion, involves complex conative and behavioral dispositions, which makes it an attractive topic of popular ethical and political discourse. For example, consider the lyrics to James Brown's song, "Say It Loud-I'm Black And I'm Proud":

67. Frederick Douglass, "John Brown," in Foner, op. cit., 633-647; 637. For related discussion of the need for public education about both White anti-racist heroes and more ordinary, "unglorious" White people who "convert" from racist ways of being, see Alcoff, op. cit., especially 188-204.

68. For an exception, see Vice, op. cit., 204-205. 
Some people say we got a lot of malice / Some say it's a lotta nerve / But I say we won't quit moving / Until we get what we deserve ... I've worked on jobs with my feet and my hands / But all the work I did was for the other man / And now we demand a chance / To do things for ourselves ... We'd rather die on our feet / Than keep living on our knees. ${ }^{69}$

It is striking that these lyrics make no reference whatsoever to any positive emotion, let alone to the emotion of pride. Numerous other popular examples share this feature.

Plausibly, "racial pride" does not always, and perhaps not even principally, refer to the emotion of pride.

As with the emotion of racial pride, there are several varieties of the character trait of racial pride. Accounting for this variety, and for the evaluative considerations that determine whether an instance of the trait is virtuous, requires further study. 